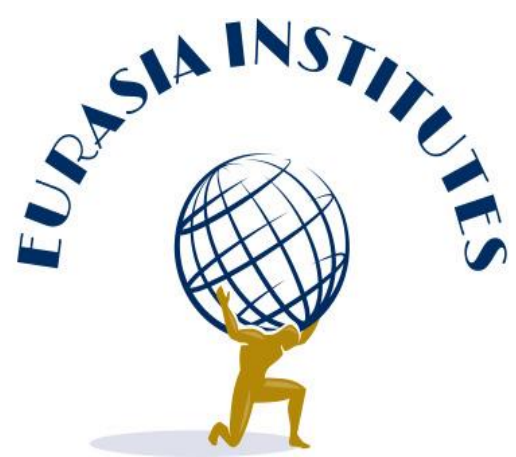

DOI: $10.47669 /$ PSPRP-1-2019

\title{
The Rise of Nationalism and Xenophobia in Putin's Russia: Implications for Immigrants from Central Asia and Caucasus
}

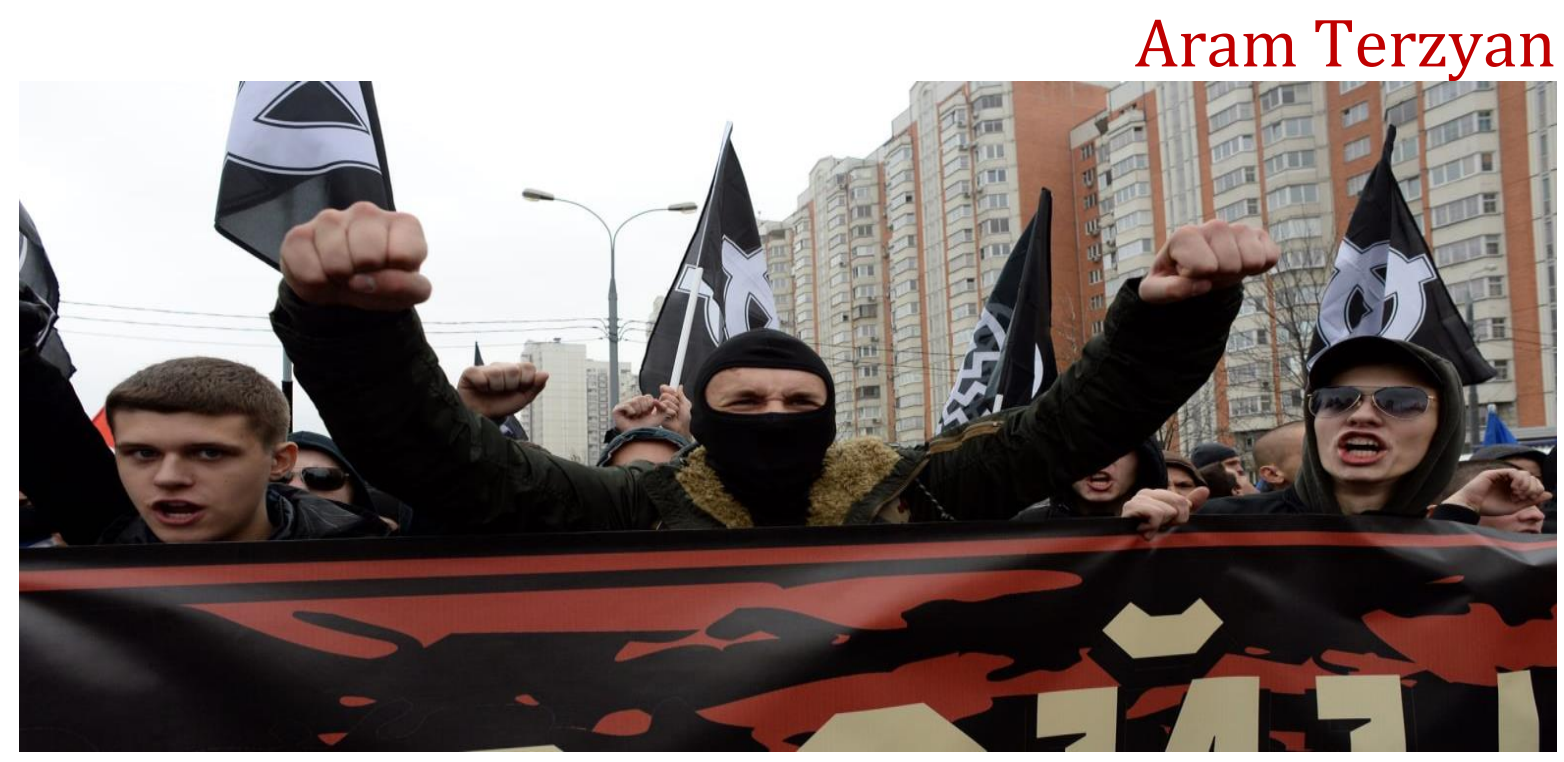

Center for East European and Russian Studies 


\begin{abstract}
This paper explores rising nationalism and xenophobia in Putin's Russia, focusing on their implications for immigrants from Central Asia and Caucasus. There is a broad consensus among the students of the Russian politics, that Vladimir Putin's presidency has led to new Russian national identity construction and rising nationalism. The major shift in Orthodox nationalism during Putin's presidency has taken its toll on immigrants, particularly from Central Asia and Caucasus. While the Kremlin would consistently strive to style the Russian nationalism as "anti-fascist," it has not done much to address mounting concerns over significant overlaps between nationalism and xenophobia. Rather, the nationalist rhetoric has well resonated with many Russians, who would take to the streets with slogans of "White Power" or "Russia for the Russians."
\end{abstract}

Key words: Russia, Nationalism, Xenophobia, Immigrants, Central Asia, Caucasus.

\title{
Introduction
}

This paper explores rising nationalism and xenophobia in Putin's Russia, focusing on their implications for immigrants from Central Asia and Caucasus.

There is a broad consensus that among the students of the Russian politics, that Vladimir Putin's presidency has led to new Russian national identity construction and rising nationalism. Exploring the nationalist discourse in Putin's Russia, Rowley (2004) contends that it would be inaccurate and misleading to apply the term 'nationalism' to Russia prior to the present day. Both Tsarist and Soviet leaders sought to maintain an empire and not a nation-state, and their national consciousness was imperial rather than national (Rowley, 2000). Some observers note that assessing the transformation of Russian nationalist discourse in the 21 st century Russian nationalism, previously dominated by 'imperial' tendencies pride in a large, strong, and multi-ethnic state able to project its influence abroad - is increasingly focused on ethnic issues. Meanwhile, this new ethno-nationalism has come in various guises, like racism and xenophobia (Kolstøand and Blakkisrud, 2016).

Given increases in hostility and violence targeting Russia's migrant minorities since the late 1990s, local and international scholars, human rights groups, and others have focused predominantly on relationships between the ethnic Russian majority and the non-Russian ethnic minorities (Alexseev, 2010). 
The Rise of Nationalism and Xenophobia in Putin's Russia: Implications for Immigrants from Central Asia and Caucasus

Exploring the nature of national exceptionalism and xenophobia, Barry (2018) sets forth the following findings: First, the belief that individuals must affiliate with their nation's dominant religion is widespread and increasing among ethnic Russians. Second, this belief is associated with some dispositions that are particularistic and xenophobic (Barry, 2019). That said, the major shift in Orthodox nationalism during Putin's presidency, has inflicted huge suffering on immigrants, particularly, from Central Asia and Caucasus - bound to experience the dire consequences of rising xenophobia.

A question remains as to what are the main implications of the rising Russian nationalism for influxes of non-Slavic immigrants.

\section{The Rise of Nationalism in Putin's Russia: Main Aspects of Russian National} Identity and Orthodox Nationalism

There is a broad consensus among the students of the Russian politics, that Vladimir Putin's presidency has led to new Russian national identity construction. Ever since taking office, Putin has regularly been characterized in Western media as a 'nationalist'(Tuminez, 2000). Some observers attribute the nationalist shifts in Russia to widening gaps between Russia and the West. While in early 1990s the West would be treated as a symbol of a high level of socioeconomic development by a significant part of the Russian elite and the wider society, the anti-western attitudes started to pick up steam during Vladimir Putin's presidency. The latter marked a shift from 'liberal ideas' to geopolitical and particularly pragmatic geo-economic realism in the Russian political thinking (Thorun, 2009, p. 28). As a result, instead of treating the West as a "role model" Putin resorted to othering it, thus leading to the establishment of an opposing ideology to the Western/European one based on Russian ethnic nationalism, conservative values and the Russian Orthodox church. Thus, Russia is widely deemed to be defining itself as a rival to the EU with the creation of the Eurasian Union and possibly constructing a Eurasian identity (Stefansson, 2015, pp. 20-21).

Not surprisingly, the 2014 Maidan Revolution in Ukraine has been viewed as a manifestation of "clash of civilizations" between Russia and Europe that heralded the end of the post-Cold war settlement and vanished the hopes of Euro-Russian integration (Shevtsova, 2014). That said, instead of joining the Western civilization, Russia positioned itself as its "Other." 
To give a better understanding of Putin's 'nationalist' agenda, Bugajski (2015) and Kuzio (2016) outline 11 main aspects of contemporary Russian national identity: 1. victimhood and the Weimar complex; 2. alleged encirclement of Russia by hostile powers and Islamic threats in the Caucasus and from Syria; 3. rising Russophobia in Ukraine, the three Baltic states and Western governments and international organizations; 4. supremacism of Russian culture and Eurasianist civilization over the West; 5. campaign for Russian unity through the gathering of Russian compatriots and lands; 6. a programme of Pan-Slavism operating through the concept of the Russkii Mir (Russian World) organization; 7. instrumental use of religion through a powerful alliance between the Russian state and the Russian Orthodox Church that treats the entire former USSR as its canonical territory, not just Russia; 8. attacks on historical revisionism (particularly dealing with World War II) in Ukraine, the 3 Baltic states, and centraleastern Europe; 9. cult of the Great Patriotic War and Joseph Stalin as a great war time leader; 10. pre-detente Cold War era anti-Americanism; and 11. dividing Europe through the provision of Russian support for populist-nationalist and fascist and extreme left parties (Kuzio, 2016, p. 2).

Clearly, Russian Orthodox Church has a special mission of promoting the 'nationalist' agenda and providing the latter with a definable moral framework. Not surprisingly, even from the outset of his presidency, Putin embarked on injecting his regime with Orthodox nationalism. He would consistently emphasize the necessity of 'spiritual renewal' that got enshrined in National Security Concept and started to influence government policies (Elkner, 2005).

Agadjanian (2017) notes that that 'traditional morality' has become the signature discourse of the Russian Orthodox Church which is attempting to construct 'tradition' by drawing upon a partly imagined ethos of imperial Russia and the late Soviet Union (Agadjanian, 2017). Meanwhile, the religious language of traditional morality has translated into a political rhetoric of solidarity and patriotism - two crucial pillars of Putin's regime.

The presidential apparatus has appeared to contribute significantly to reinforcing Orthodox nationalism through state programs that promote religious and patriotic education. A 2009 directive allowed religious education in public schools, while an Orthodoxy module introduced in 2012. According to widely held beliefs the Church successfully uses this course not only to boost its own position in Russian society, but also to promote its vision of the Russian national identity (Lamoreaux and Flake, 2018, pp. 1-4). Moreover, so-called 
The Rise of Nationalism and Xenophobia in Putin's Russia: Implications for Immigrants from Central Asia and Caucasus

'Yarovaya Law', adopted in 2016, further reinforced the unlevel religious playfield in favor of the Orthodox Church (Lamoreaux and Flake, 2018, pp. 1-4). Overall, the Kremlin's efforts at promoting Orthodox nationalism have proved successful. Surveys show that Russians trust the Orthodox Church more than any other public institution, including law courts, trade unions, mass media, the military, the police, and the government (Knox, 2005).

\section{Nationalism and Xenophobia}

According to widely-held beliefs, the Kremlin's nationalist agenda aims at "exiting from the political" as the national is designed to distract attention from pressing domestic issues, along with justifying the development of authoritarian practices (Khachaturian, 2009).

Moreover, the shift in nationalism has been positively correlated with rising populism and xenophobia. The country's major political figures have gone with the flow, notably by concentrating on those issues which are most electorally significant, including xenophobia toward "Southerners"; demographic anxieties; concern over the balance between "Russians" and "national minorities," etc. (Khachaturian, 2009, pp. 20-21).

The wave of xenophobia that keeps persisting in Russia, dates to Boris Yeltsin's presidency in the 1990s, specifically targets the ethnic groups from the Caucasus and Central Asia. The influx of these people into Russia, either as refugees or laborers desperate for work, has incited many Russians' animosity. The notorious Vladimir Zhirinovsky, leader of the Liberal Democratic Party of Russia, has been vocal about his discontent with migration influxes from Central Asia, while calling for patriotism and Russian territorial expansion in Russia. He went so far as to bringing up the issue of introducing visa requirements for nationals from Central Asian states (Global Voices, 2013). Other right-wing organizations that appeared in the nineties were even more concerning.

An extreme example is the disbanded Russian National Unity (RNU), which has been largely regarded as a racist Nazi party. The party based itself on four principles i.e. Orthodox Christianity, a strong state, aggressive Russian nationalism, and non-Marxist socialism (Horvath, 2018).

The RNU also found official support in regional administrations, particularly in the Stavropol and Krasnodar territories of southern Russia, hosting huge number of immigrants 
from the Caucasus. Notably, it was not uncommon for RNU members to "patrol" public parks and harass demonstrators, thus striving to suppress pluralism and dissent (Khachaturian, 2009, p. 20).

Not surprisingly, violence against minorities and foreigners has been on the rise in recent years. Small but well-organized neo-Nazi skinhead gangs' stage random attacks on persons, who have non-Slavic features, especially those from Central Asia and Caucasus, who have significantly darker hair and skin colors than Russians. The SOVA Center, a Russian nongovernmental organization that studies radical right-wing organizations, reported that from 2004 to 2007 there were 1,049 racially motivated attacks in Moscow and St. Petersburg alone, with 140 fatalities (Khachaturian, 2009, p. 20). According to the SOVA Center surveys, at least 57 people suffered from racist and other ideologically motivated violence in 2018; at least 4 of these died, the rest were injured (Yudina, 2019).

Ironically, police tend to tacitly support anti-immigrant discrimination, most vividly by recording racially motivated attacks by skinheads as minor incidents of hooliganism. Moreover, people of foreign appearance are also consistently targeted for passport and registration checks. In the fall of 2006, when tensions between Russia and Georgia were rising, the Russian government launched a massive crackdown on Georgians living in the country. More specifically, in October and November of 2006, under the banner of 'fight against irregular migration and organized crime' Russian authorities detained thousands of Georgians and expelled more than 2,300 of them to Georgia, including many Georgians residing legally in Russia. Credible reports suggest that detentions occurred with blatant disregard for basic human rights and decency. Georgians were held in appalling conditions and were subjected to a wide range of abuses amounting to torture. Two Georgians died in custody awaiting expulsion (Human Rights Watch, 2007). The Russian Government's campaign against ethnic Georgians occurred in the context of Georgia's growing attempts to redefine inherently asymmetric relations with Russia and thus pull the country out of the Russian authoritarian influence. To punish Georgia's 'deviant behavior', along with other measures, targeted Georgian population in Russia. Russian officials made repeated public statements framing Georgians as illegal immigrants, criminals, and calling for measures to be taken against them. Russian television stations, the largest of which are owned or controlled by people close to the Russian Government, actively supported and justified the latter's discrimination against Georgians through daily news programs and other programming, and often quoted senior officials making strong anti-Georgian statements 
The Rise of Nationalism and Xenophobia in Putin's Russia: Implications for Immigrants from Central Asia and Caucasus

(Human Rights Watch, 2007). Concurrently, Moscow police began to conduct widespread "document inspections" of ethnic Georgians. Some police officers targeted locations where Georgians were likely to assemble, such as the entrance to the Georgian embassy and to the Georgian Orthodox Church in Moscow. In several districts of Moscow, police demanded that schools produce lists of names of all ethnic Georgian children and their parents (Human Rights House, 2006). The crackdown spilled over into other parts of Russia and resulted in unlawful detention of thousands of ethnic Georgians. All this prompted Georgian President Micheil Saakashvili to posit that Russia cannot simply tolerate Georgia's transformation into a European democratic and prosperous and state, which would no longer be susceptible to Russian coercive policy. Georgia's experience of successful reforms and the path to European democracies angered Russia and prompted to 'correct its deviant behavior' with the view to hinder democracy promotion throughout the post-Soviet region. 'This is why the Georgian nation has suffered an embargo, a war, an invasion, and an occupation - all since 2006' (Saakashvili, 2013). The situation came to head in 2008, fraught with the war incited against 'disobedient' Georgia, with all ensuing consequences. In Saakashvili's words, Russian aggression came as no surprise given its resolution to crush the young democracy "After a long embargo, economic blockades, provocations, bombardments, threats, boycotts and other rough but finally not successful pressures of the old KGB followers decided to finish the so-called "Georgian project", our common attempt to create a modern, European, democratic, successful state in Caucasus" (Saakashvili, 2009). Overall, along with other issues, the mistreatment of Georgian population in Russia sent ripples of apprehension into Armenia and alarmed the repercussions of 'angering' Russia. No wonder, the Armenian leadership framed the decision to join the Russian-led Eurasian Union as inevitable, repeatedly citing its positive implications for the Armenian community (Terzyan, 2017, p. 191). There has been a broad consensus among the representatives of Armenia's political leadership* that despite the resentment that Russian policy may generate, Armenia should avoid 'provoking' Russia. Otherwise, the latter would severely punish Armenia's 'disobedience', not least through cracking down on the Armenians living in Russia (Aberg and Terzyan, 2018, p. 168).

\footnotetext{
* Note: Several officials provided valuable insights but asked not to be cited in an attributable way.
} 


\section{Anti-Fascist Nationalism?}

While there has been a blurred line between nationalism and fascism in Russia, the Kremlin have consistently strived to style the Russian patriotism as inherently anti-fascist.

Remarkably, the government youth movement Nashi (Ours), that emerged in 2005 as a pro-regime support group claimed to be an anti-fascist movement. While pretending to be an independent youth movement, Nashi was state-run, with inherently anti-Western and antiliberal ideas. Nashi was claiming to adhere to seemingly incompatible values, combining the elements of democratic discourse and global youth culture with nationalism and "moral framework" of the Russian Orthodox Church (Hemment, 2015, pp. 72-73). Even though Nashi's priorities would considerably change over time in response to Kremlin's shifting priorities, it did not cross the line of a pro-regime counter-revolutionary movement, aimed at filling the public space with nationalism and loyalty to the regime. As a result, Nashi would passionately support the Putin regime, not least through countering anti-Putin opposition demonstrations in Moscow in December 2011 (Atwal and Bacon, 2011). Not surprisingly, Nashi would be widely regarded as evidence of an anti-democratic backlash and as confirmation of Russia's resurgent authoritarianism (Hemment, 2012, p. 234). That said, Nashi had nothing to do with a democratic civil society and served as a tool for controlling public space and countering the opposition (p. 234). It further fueled anti-Western attitudes, while serving Putin's agenda for promoting nationalism across the country.

The anti-fascist discourse significantly intensified in the wake of the Ukrainian crisis. Notably, the Russian propaganda would treat the 2014 Maidan Revolution as a resurgence of "nazism" and "fascism" in Europe citing the "coup d'etat" in Ukraine: "those who stood behind the latest events in Ukraine resorted to terror, murder and riots. Nationalists, neoNazis, Russophobes, and anti-Semites executed this coup. They continue to set the tone in Ukraine to this day (Putin, 2014). Consistent with the Kremlin's discourse, there has been a strong tendency in Russian media to frame the Ukrainian crisis as a struggle against "fascism." This framing considerably owes to the distinctive shape of the post-Soviet Russian collective memory, that has been a crucial factor enabling the successful use of the "fascism" frame (Gaufman, 2015). The references to the revival of fascism would be followed by the claim, that as a pivotal actor in defeating fascism through World War II, Russia had a crucial mission of preventing the revival of fascism in Europe. 
The Rise of Nationalism and Xenophobia in Putin's Russia: Implications for Immigrants from Central Asia and Caucasus

Overall, while the Kremlin would consistently strive to shield nationalism from "fascist" accusations, it has not done much to address mounting concerns over the overlaps between nationalism and xenophobia.

Rather, the nationalist rhetoric would well resonate with many Russians, who would take to the streets chanting slogans, such as "White Power," "Russia for the Russians." Essentially, many ordinary Russians have been deeply hostile to immigrants from Central Asia and the Caucasus, blaming them for problems such as crime and unemployment. The hardline nationalists would call for "stopping immigrants from coming into Moscow," as well as giving them land "so that they live like monkeys, like the Americans did with the Indians" (Reuters, 2013). The Levada-Centre surveys reveal about half of the surveyed population believes in violent conflicts based on ethnic grounds, while around a third of respondents stated that 'residence in Russia for natives of Caucasus and Central Asia must be limited', while only a quarter of the survey participants insist that 'no measure of restriction should be imposed on residents who are foreign born' (Kislov and Zhanaev, 2017).

To give a better understanding of public attitudes towards migrants in Russia, it is noteworthy that in early 2017 the Deputy Prime Minister of Russia Olga Golodets accused migrants of undermining development in Russia, having 'low qualifications and being a burden for social services with their families needing education and care,' with a 'negative surplus' for the economy, and called on employers to refuse cheap and unqualified labor in favor of highly productive labor (Kislov and Zhanaev, 2017).

Clearly, such attitudes pose formidable challenges to migrants and immigrants from Central Asia and Caucasus, who would not feel safe amid hatred, pervasive racism, and xenophobia.

It has not been uncommon for Russian police officers in Russia take documents from migrants as a form of extortion, as well as to arbitrarily detain Central Asian migrant workers. Namely, in mid-December 2019, the police forces carried out raids in at least six regions in Russia, detaining migrant workers without legal basis. "Racial profiling, mass detentions, and ill-treatment in police custody of migrant workers and Russians of non-Slavic appearance is unlawful and unjust," said Hugh Williamson, Europe and Central Asia director at Human Rights Watch and called for immediately stopping arbitrary detentions (Human Rights Watch, 2019). Strikingly, a Central Asian immigrant notes that "Even if we could stand the 
unfriendliness of Russians toward us, the police, who literally rob and degrade us, don't let us live in peace" (Central Asia News, 2018). That said, the rising nationalism, xenophobia, as well as rampant corruption condemn the migrants from Central Asia and Caucasus to a great deal of mistreatment, discrimination, and abuses across Russia.

\section{Nationalism and Eurasianism}

One of the intriguing questions regarding the Russian nationalism, is its relationship with foreign policy, not least towards Central Asia and South Caucasus. This provokes an inquiry into Eurasianism and the Kremlin's Eurasian foreign policy agenda.

According to widely held beliefs, the Russian-led Eurasian integration aims at reorganizing the post-Soviet space and shielding the latter from unwanted Western 'intrusions' (Kaczmarski, 2017; Kirkham, 2016). Alexander Dugin, one of its best-known proponents, believes that the demise of the Soviet Union was simply a tragic incident. The people of the former USSR should again be united in a grand Eurasian empire, with Russia a benign and generous patron, providing its "younger brothers" clients economic largesse and defense, mostly against the predatory USA (Shlapentokh, 2007). Morozova (2009) notes that on the level of practical geopolitical reasoning Eurasianism is reduced to geopolitics, i.e. the politics of spheres of influence and hegemonic spatial control, while Eurasian identity construction is dismissed as unconvincing, strategic and self-serving (Morozova, 2009).

Clearly, the construction of the Eurasian identity is inherently linked to the promotion of the Russian language in Eurasian Union member countries and beyond. Namely, within its strategy for Eurasian integration Russia has routinely pushed for Russian language adoption as official language in Armenia. This policy is consistent with Russian President Vladimir Putin's discourse on "Russian world" (Zevelev, 2016) - Russian - dominated union of post-Soviet countries, where the promotion of Russian language is a way to step up Russian cultural, economic and political influence over those countries. During his visit to Armenia in 2014 the Kremlin's outstanding media personality D. Kiselyov noted that 'if Armenians want to feel safe, they have got to speak Russian...Russian culture is becoming of secondary importance. Russia, in the Collective Security Treaty Organization framework, took upon itself providing security for Armenia. And what is happening to the Russian language in Armenia? It is simply disappearing.... The question is what is Armenia doing not to let this happen" (Eurasianet, 2014). Similarly, former Russian ambassador to Armenia V. Kovalenko noted "You can't choose one union for security-related integration and another one for cultural purposes" (Eurasianet, 2014). It follows, that Armenia is forced to put aside 
The Rise of Nationalism and Xenophobia in Putin's Russia: Implications for Immigrants from Central Asia and Caucasus

its own identity and preferences and abide by Russian economic, political, and cultural rules. No wonder, in 2017 Russian officials suggested that it might be a good idea for Armenia to adopt Russian as an official language. The suggestion emerged after the Russian Duma adopted a law, on July 12, 2017 allowing drivers from Eurasian Union countries to work as commercial drivers in Russia, but only if those countries recognize Russian as an official language. "In this way we're providing encouragement to governments which respect the Russian language and enshrine it in their constitutions and recognize it officially," said Leonid Kalashnikov, a Duma member and one of the law's authors (Eurasianet, 2017). In practice that means that to avoid further inconvenience, Armenia would have to follow the paths of Belarus, Kazakhstan, and Kyrgyzstan -- all of which recognize Russian as an official language. Overall, there appears to be a close relationship between nationalism and Eurasianism, and the latter can be viewed as the foreign policy projection of the Russian nationalism.

\section{Conclusion}

This article contributes to the existing literature and ongoing debate regarding the anatomy of nationalism and xenophobia and their practical implications in Putin's Russia. The previous discussion suggests that the Kremlin's 'nationalist' agenda has aimed at "exiting from the political" as the national is designed to distract attention from pressing domestic issues, along with justifying the development of authoritarian practices. While there has been a major shift in Orthodox nationalism during Putin's presidency, the rising xenophobia has specifically targeted the ethnic groups from the Caucasus and Central Asia.

While the Kremlin would consistently strive to style the Russian nationalism as inherently 'anti-fascist', it has not done much to address mounting concerns over significant overlaps between nationalism and xenophobia. Rather, the nationalist rhetoric has well resonated with many Russians, who would take to the streets with slogans of "White Power" or "Russia for the Russians."

There is a close relationship between nationalism and Eurasianism, and the latter can be viewed as the foreign policy projection of the Russian nationalism. Against this backdrop, the Kremlin would further intensify its efforts at constructing Eurasian identity, while promoting and expanding the ranks of the Russian-led Eurasian Union. 


\section{References}

Aberg, J. H. and Terzyan, A. (2018), Structure or agency? Explaining Armenia's foreign policy evolution. Eastern Journal of European Studies, 9(1), pp. 151-172

Agadjanian, A. (2017). Tradition, morality and community: elaborating Orthodox identity in Putin's Russia. Religion, State \& Society, 45(1), pp. 39-60.

Alexseev, M. A. (2010). Majority and minority xenophobia in Russia: The importance of being titulars. Post-Soviet Affairs, 26(2), pp. 89-120.

Atwal, M. and Bacon, E. (2012). The Youth Movement Nashi: Contentious Politics, Civil Society, and Party Politics, East European Politics, 28(3), pp. 256-266.

Barry, D. (2019). Ethnodoxy, national exceptionalism, and xenophobia: a case study of contemporary Russia. National Identities, 21(3), pp. 223-239.

Central Asia News (2018). Central Asian migrants describe injustice, racism in Russia (retrieved from https://central.asianews.com/en_GB/articles/cnmi_ca/features/2018/07/03/feature-01).

Elkner, J. (2005). Spiritual security in Putin's Russia. History \& Policy, Policy Papers, 1 (retrieved from http://www.historyandpolicy.org/policy-papers/papers/spiritualsecurity-in-putins-russia).

Eurasianet (2014), Kremlin Propaganda-Chief Asks Armenians to Speak Russian, (retrieved from https://eurasianet.org/kremlin-propaganda-chief-asks-armenians-to-speakrussian).

Eurasianet (2017). Russian-Armenian Tycoon Expanding Influence in Armenia (retrieved from https://eurasianet.org/russian-armenian-tycoon-expanding-influenceinarmenia).

Gaufman, E. (2015). Memory, media, and securitization: Russian media framing of the Ukrainian crisis. Journal of Soviet and Post-Soviet Politics and Society, 1(1), pp. 141-175.

Global Voices (2013). From Russia with no love...for Central Asia (retrieved from https://globalvoices.org/2013/05/03/central-asia-from-zhirinovsky-with-love/).

Hemment, J. (2012). Nashi, Youth Voluntarism, and Potemkin NGOs: Making Sense of Civil Society in Post-Soviet Russia, Slavic Review, 71(2), pp. 234-260.

Hemment, J. (2015). Youth Politics in Putin's Russia: Producing Patriots and Entrepreneurs. Indiana University Press.

Horvath, Z. (2018). Introduction to Russian neo-Nazis (retrieved from https://www.crwflags.com/fotw/flags/ru\%7Dnaz.html).

Human Rights House (2006). Xenophobia is on the state level, (retrieved from https://humanrightshouse.org/articles/xenophobia-is-on-the-state-level/).

Human Rights Watch (2007). Singled Out: Russia's Detention and Expulsion of Georgians, 30 September (retrieved from https://www.hrw.org/report/2007/09/30/singledout/russias-detention-and-expulsiongeorgians\#).

Human Rights Watch (2019). Russia: Police round up migrant workers (retrieved from https://www.hrw.org/news/2019/12/24/russia-police-round-migrant-workers ).

Khachaturian, R. (2009). The specter of Russian nationalism. Dissent, 56(1), pp. 1924. 
The Rise of Nationalism and Xenophobia in Putin's Russia: Implications for Immigrants from Central Asia and Caucasus

Kislov, D. and Zhanaev, E. (2017). Russia: Xenophobia and vulnerability of migrants from Central Asia, Foreign Policy Centre (retrieved from https://fpc.org.uk/russiaxenophobia-vulnerability-migrants-central-asia/).

Knox, Z. (2005). Russian Orthodoxy, Russian Nationalism, and Patriarch Aleksii II. Nationalities Papers, 33(4), pp. 533-545.

Kolst $\varnothing$, Pal, and Helge Blakkisrud, The new Russian nationalism. Edinburgh University Press, 2016.

Kuzio, T. (2016). Nationalism and authoritarianism in Russia: Introduction to the special issue. Communist and post-communist studies, 49(1), pp. 1-11.

Lamoreaux, J. W. and Flake, L. (2018). The Russian Orthodox Church, the Kremlin, and religious (il) liberalism in Russia. Palgrave Communications, 4(1), pp. 1-4.

Morozova, N. (2009). Geopolitics, Eurasianism and Russian foreign policy under Putin. Geopolitics, 14(4), pp. 667-686.

Putin (2014). Address by the President of Russian Federation (retrieved from http://en.kremlin.ru/events/president/news/20603).

Reuters (2013). Thousands of Russian nationalists rally in anti-immigrant protests (retrieved from https:/www.reuters.com/article/us-russia-nationalists/thousands-of-russiannationalists-rally-in-anti-immigrant-protests-idUSBRE9A30FN20131104 ).

Rowley, D. G. (2000). Imperial versus national discourse: the case of Russia. Nations and Nationalism, 6(1), pp. 23-42.

Saakashvili (2009). The President of Georgia Mikheil Saakashvili’s speech delivered at the ceremony dedicated to Russia-Georgian war anniversary, 7 August (retrieved from http://

www.saakashviliarchive.info/en/PressOffice/News/SpeechesAndStatements?p=2247\&i=1).

Saakashvili (2013). Address by the President of Georgia at the 68th session of the United Nations General Assembly, 25 September (retrieved from http://www. saakashviliarchive.info/en/PressOffice/News/SpeechesAndStatements?p=8465\&i=1).

Shevtsova, L. (2014), The Maidan and Beyond: The Russia Factor. Journal of Democracy, 25(3), pp. 74-82.

Shlapentokh, D. (2007). Dugin, Eurasianism, and Central Asia. Communist and PostCommunist Studies, 40(2), pp. 143-156.

Stefánsson, V. (2015), Is Russia Europe's Other? How the Ukraine Crisis Reinforces European Identity Formation (Doctoral dissertation) (retrieved from https://skemman.is/bitstream/1946 /22766/3/Is\%20Russia\%20Europe\% 27s\%20Other\%20Skemman-PDF.pdf ).

Terzyan, A. (2017), The EU vs. Russia in the Foreign Policy Discourse of Armenia: the Fragility of Normative Power or the Power of Russian coercion? Eastern Journal of European Studies, 8(2), pp. 185-203.

Thorun, C. (2008). Explaining Change in Russian Foreign Policy: The Role of Ideas in Post-soviet Russia's Conduct Towards the West. Springer. 
Tuminez, A. (2000). Russian Nationalism and Vladimir Putin's Russia. Policy Memo, 151 (retrieved from https://www.ponarseurasia.org/sites/default/files/policy-memos-pdf/pm_0151.pdf).

Yudina, N. (2019). Far Right and Arithmetic: Hate Crime in Russia and Efforts to Counteract It in 2018 (retrieved from https://www.sova-center.ru/en/xenophobia/reportsanalyses/2019/02/d40603/).

Zevelev, I. (2016), The Russian World in Moscow's Strategy (retrieved from https://www.csis.org/analysis/russian-world-moscows-strategy). 